\title{
Global Loss of Na,K-ATPase and Its Nitric Oxide-Mediated Regulation in a Transgenic Mouse Model of Amyotrophic Lateral Sclerosis
}

\author{
Dorette Z. Ellis, Jason Rabe, and Kathleen J. Sweadner \\ The Neuroscience Center, Massachusetts General Hospital, Charlestown, Massachusetts 02129
}

\begin{abstract}
$\mathrm{Na}$,K-ATPase plays a critical role in energy metabolism and ion fluxes. Its loss was investigated in the G93A mouse model of amyotrophic lateral sclerosis (ALS) in which the mutation of $\mathrm{Cu} / \mathrm{Zn}$ superoxide dismutase (SOD1) is thought to lead to aberrant oxidative damage. Observed losses in spinal cord Na,K-ATPase activity exceeded all expectations. All three catalytic subunit isoforms $(\alpha 1, \alpha 2, \alpha 3)$ were reduced, and the global $\alpha$ subunit loss affected not just neurons, glia, and myelinated axon tracts but even ependymal and pial membranes. Decreases in Na,K-ATPase activity were greater than losses of protein, and there were losses of Na,K-ATPase $\alpha$, but not $\beta$, subunits. Together, these observations are consistent with selective degradation of the $\alpha$ subunit after damage. Overexpression of normal SOD1 does not cause ALS-like symptoms, but it has other known pathological effects. In transgenic mice overexpressed normal human SOD1 had a smaller but still considerable effect on Na,K-ATPase. Furthermore, the nitric oxide-mediated regulatory pathway for Na,KATPase inhibition was undetectable in spinal cord tissue slices from mice overexpressing either mutant or normal human SOD1. Na,KATPase activity did not respond to nitric oxide donors, and the free radical-dependent step of the pathway could not be bypassed by the addition of the downstream protein kinase $\mathrm{G}$ activator, 8 -Br-cGMP. The data demonstrate that Na,K-ATPase is vulnerable to aberrant SOD1 activity, making it a potential contributing factor in disease pathology. Moreover, the global cellular distribution of Na,K-ATPase loss indicates that SOD1 overexpression is far-reaching in its pathological effects.
\end{abstract}

Key words: Na,K-ATPase; SOD1; amyotrophic lateral sclerosis; neurodegeneration; spinal cord; nitric oxide

\section{Introduction}

Amyotrophic lateral sclerosis (ALS) is an age-dependent motor neuron disease. Certain familial ALS cases are inherited as an autosomal dominant trait with mutations in cytosolic $\mathrm{Cu} / \mathrm{Zn}$ superoxide dismutase 1 (SOD1) (Rosen et al., 1993; Brown, 1995). SOD1 normally converts superoxide, a by-product of mitochondrial metabolism, to water and hydrogen peroxide. Simple loss of SOD1 activity has been ruled out as a cause of the disease. Instead, there is evidence for "gain of toxic function," such as increases in copper-, free radical-, or oxidative damage, which is not alleviated by increases or decreases in the level of normal SOD1 activity (Cleveland and Rothstein, 2001; Julien, 2001).

The Na,K-ATPase consumes $50 \%$ of the energy supply in the CNS (Ames, 2000). Its catalytic ( $\alpha$ ) subunit is sensitive to damage by free radicals and other oxidative stress (Kim and Akera, 1987; Xie et al., 1995; Mense et al., 1997), and the oxidized Na,KATPase $\alpha$ subunit can be degraded by calpain, proteosomal, and lysosomal pathways (Zolotarjova et al., 1994; Thevenod and Friedmann, 1999). It thus may be one of the links between alterations in free radical homeostasis and ALS pathology. In other

Received June 27, 2002; revised Sept. 30, 2002; accepted 0ct. 4, 2002.

This work was supported by grants from the Amyotrophic Lateral Sclerosis Association and the Fiftieth Anniversary Scholars Program of Harvard Medical School to D.Z.E. and by National Institutes of Health Grant R01-NS27653 to K.J.S. We thank Dr. Robert H. Brown Jr. (Massachusetts General Hospital) for advice and stimulating discussions. We are also grateful to Drs. J. Kyte, P. Martin-Vasallo, C. Goridis, and M. Schachner for antibodies.

Correspondence should be addressed to Dr. Kathleen J. Sweadner, 149-6118, Massachusetts General Hospital, 149 13th Street, Charlestown, MA 02129. E-mail: sweadner@helix.mgh.harvard.edu.

Copyright $\odot 2002$ Society for Neuroscience $\quad$ 2270-6474/02/220043-09\$15.00/0 circumstances the inhibition of Na,K-ATPase increases the sensitivity of neurons to glutamate excitotoxicity because of complementary effects on neurons (enhancing glutamate effects and $\mathrm{Ca}^{2+}$ accumulation) and astrocytes (reducing the driving force for $\mathrm{Na}^{+}$-dependent glutamate clearance) (Lees et al., 1990; Brines and Robbins, 1992; Brines et al., 1995; Calabresi et al., 1995; Lees and Leong, 1996; Stelmashook et al., 1999). Furthermore, the free radical nitric oxide (NO*) normally regulates the $\mathrm{Na}, \mathrm{K}-\mathrm{ATP}$ ase via the activation of soluble guanylate cyclase and cGMP (McKee et al., 1994), a pathway that is shared by glutamate and oxygen free radicals in the CNS. This pathway forms a convergence point for the action of several intercellular and intracellular molecular messengers that have been implicated in neuronal viability under stress (Dawson et al., 1991; Nathanson et al., 1995). Together, these suggest that either loss or excessive inhibition of Na,K-ATPase could contribute to motor neuron death via direct oxidative damage or via the enhancement of $\mathrm{NO} \cdot$ and other free radical effects.

The Na,K-ATPase has two required subunits, $\alpha$ and $\beta$. There are three $\alpha$ isoforms $(\alpha 1, \alpha 2$, and $\alpha 3)$ and three $\beta$ isoforms $(\beta 1$, $\beta 2$, and $\beta 3$ ) in the CNS (Sweadner, 1989; Blanco and Mercer, 1998), which have different kinetic properties and are likely to be regulated differently (Blanco and Mercer, 1998; Crambert et al., 2000). Although there are many exceptions to the rule, neurons have predominantly $\alpha 3 \beta 1$ and astrocytes have predominantly $\alpha 2 \beta 2$, whereas both neurons and glia can express $\alpha 1$.

To test the hypothesis that $\mathrm{Na}, \mathrm{K}$-ATPase loss occurs in a mouse model of ALS and in SOD1 overexpression, we used transgenic mice that express either human SOD1 with the G93A mis- 
sense mutation or normal human SOD1 over and above normal mouse SOD1 (Gurney et al., 1994).

\section{Materials and Methods}

Reagents. Routine reagents, sodium nitroprusside (SNP), superoxide dismutase, and ouabain were purchased from Sigma (St. Louis, MO). ${ }^{1} \mathrm{H}-$ [1,2,4] oxadiazolo[4,3-a]quinoxalin-1-one (ODQ), diethylenetriamine NO (DETA-NO), 8-Br-cGMP, and okadaic acid were obtained from Sigma-RBI (Natick, MA). The cGMP enzyme immunoassay system was purchased from Amersham Biosciences (Piscataway, NJ). Cy3conjugated goat-anti mouse IgG was purchased from Jackson ImmunoResearch Laboratories (West Grove, PA). The Puregene DNA Isolation Kit was purchased from Gentra (Minneapolis, MN).

Transgenic SOD1 mice. The mice were obtained from Dr. Robert $\mathrm{H}$. Brown Jr. (Massachusetts General Hospital, Charlestown, MA) or The Jackson Laboratory (Bar Harbor, ME) and were strains originally developed by Dr. Mark Gurney (Gurney et al., 1994). The G1H strain of G93A mice carries high copy numbers of human SOD1, with a missense mutation substituting glycine with alanine at codon 93, and develops ALS-like symptoms between 3 and 4 months of age. This strain is maintained as a hemizygote hybrid line, progeny of a cross between C57BL/6J and SJL mice. Transgenic males were crossed with nontransgenic B6SJL-F1 females. Animals were genotyped by purifying mouse tail DNA with a Puregene DNA Isolation Kit; PCR products were separated on a $2 \%$ agarose gel. The controls were transgenic normal human SOD1 overexpressors of the B5SJL strain and nontransgenic littermates.

$\mathrm{Na}, \mathrm{K}$-ATPase activity and cGMP measurements. Whole spinal cord tissue was dissected, and tissue slices $(0.4 \times 0.4 \times 1 \mathrm{~mm})$ were prepared on a Brinkmann chopper cooled to $4^{\circ} \mathrm{C}$ and suspended $(25-30 \mathrm{mg} / \mathrm{ml}$ wet weight) in microdissection buffer containing (in $\mathrm{mm}$ ): $137 \mathrm{NaCl}, 5$ $\mathrm{KCl}, 0.8 \mathrm{MgSO}_{4}, 0.25 \mathrm{CaCl}_{2}, 1.0 \mathrm{MgCl}_{2}, 10 \mathrm{HEPES}$, and $2 \mathrm{NaOH}, \mathrm{pH}-$ adjusted to 7.4 at $34^{\circ} \mathrm{C}$.

SNP, DETA-NO, or 8-Br-cGMP, when used, was added to tubes that contained $1 \mathrm{ml}$ aliquots of slice suspension. Tubes were incubated for 15 min at $34^{\circ} \mathrm{C}$ with rocking and then frozen at $-80^{\circ} \mathrm{C}$. In studies that used ODQ or okadaic acid, the inhibitor was added 3 min before the addition of the other drug. Tubes were thawed and centrifuged $(1700 \times g$ for 15 $\min$ at $4^{\circ} \mathrm{C}$ ), and the supernatant was removed and assayed for cGMP by using an enzyme immunoassay according to the manufacturer's instructions. The tissue slice pellets were resuspended in resuspension buffer containing (in mM): $85 \mathrm{NaCl}, 20 \mathrm{KCl}, 4 \mathrm{MgCl}_{2}, 0.2 \mathrm{EGTA}$, and 30 histidine, $\mathrm{pH}$-adjusted to 7.2 .

Two similar ATPase assays were used. For most experiments with tissue from 4-month-old animals the Na,K-ATPase activity was determined by using the pyruvate kinase/lactate dehydrogenase assay that couples the generation of ADP and oxidation of NADH as described previously (Ellis et al., 2000). Treated tissue slices were homogenized with a ground glass homogenizer. Na,K-ATPase activity was calculated from the difference between the slopes in the time course of absorption change at $340 \mathrm{~nm}$ in the absence and the presence of $3 \mathrm{~mm}$ ouabain. For most experiments with tissue from 2-month-old animals the activity was determined by the colorimetric ATPase assay: ATP was hydrolyzed, and the released $\mathrm{P}_{\mathrm{i}}$ was measured by forming a complex with molybdate. The pelleted tissue slices were resuspended and refrozen for at least $20 \mathrm{~min}$ at $-80^{\circ} \mathrm{C}$ in $1 \mathrm{ml}$ of resuspension buffer. Tubes were thawed on ice water. For further permeabilization saponin $(20 \mu \mathrm{g} / \mathrm{ml})$ was added, and the slices were incubated for $10 \mathrm{~min}$ at $34^{\circ} \mathrm{C}$. Aliquots of tissue slices $(\sim 10-15 \mu \mathrm{g}$; 7.5-10 $\mu \mathrm{l}$ ) were added to $300 \mu \mathrm{l}$ of ATPase buffer containing (in $\mathrm{mM}$ ): 3 ATP, $140 \mathrm{NaCl}, 20 \mathrm{KCl}, 3 \mathrm{MgCl}_{2}$, and 30 histidine, $\mathrm{pH} 7.2$, with or without $3 \mathrm{~mm}$ ouabain. In this and previous work we verified the equivalence of the two assays that were used (Ellis et al., 2000).

Immunoblots. Spinal cord tissue was dissected from transgenic mutant SOD1 mice, transgenic normal human SOD1 overexpressors, and nontransgenic littermate controls and then homogenized at $4^{\circ} \mathrm{C}$ in microdissection buffer. Protein concentrations were determined by the Lowry method, and samples ( $50 \mu \mathrm{g}$ of protein) were separated by gel electrophoresis on Laemmli gels and transferred to nitrocellulose membrane electrophoretically. For detection of Na,K-ATPase subunits the isoformspecific monoclonal antibodies used were 6F (for $\alpha 1$; Developmental Studies Hybridoma Bank, Iowa City, IA), McB2 (for $\alpha 2$ ), and XVIF9G10 (for $\alpha 3$; Affinity BioReagents, Neshanic Station, NJ), all of which bind in the first 60 residues of the respective $\alpha$ subunits; rabbit polyclonal antibodies SpETb1 and SpETb2 (gift of P. Martin-Vasallo, University of Tenerife, Spain) were used for $\beta 1$ and $\beta 2$, respectively. Anti-KETYY against the $\alpha \mathrm{C}$ terminus (gift of Dr. J. Kyte, University of California, San Diego, CA) was used to detect all $\alpha$ isoforms together. Anti-superoxide dismutase $(\mathrm{Cu} / \mathrm{Zn})$ polyclonal antibody specific to human SOD1 (Calbiochem-Novabiochem, San Diego, CA) was used to quantify the level of overexpressed enzyme. Blots subsequently were stained with horseradish peroxidase-conjugated secondary antibody, developed with luminol reagent, and quantified with a Molecular Dynamics scanning densitometer (Sunnyvale, CA).

Immunofluorescence. Nontransgenic controls and transgenic mutant SOD1 mice were anesthetized and perfused with PBS, followed by periodate-lysine-paraformaldehyde fixative for $20 \mathrm{~min}$ (McLean and $\mathrm{Na}$ kane, 1974). The spinal cords encased in the vertebral columns were harvested and postfixed for $48 \mathrm{hr}$. The spinal cords were removed and washed in PBS overnight and then soaked in $25 \%$ sucrose in $0.1 \mathrm{M}$ PBS for $24 \mathrm{hr}$ before sectioning. Cryostat sections $(10-14 \mu \mathrm{m})$ were cut at $-20^{\circ} \mathrm{C}$ and collected on positively charged slides (ProbeOn Plus, Fisher Scientific, Durham, NC). Slides were washed in $0.1 \mathrm{M}$ PBS and incubated in blocking buffer containing $0.1 \%$ Triton X-100 and 5\% normal goat serum in PBS. Tissue sections were incubated with primary monoclonal antibodies for the $\alpha$ subunits described above, washed, and stained with secondary antibody Cy3-conjugated goat-anti mouse IgG. For $\beta 1$, monoclonal antibody BSP-3 was used, a gift of Dr. C. Goridis (INSERMCNRS, Marseille Luminy, France). For $\beta 2$, monoclonal antibody 426 was used, a gift of Dr. Melitta Schachner (University of Hamburg, Germany). The images were viewed with a Zeiss confocal microscope (Oberkochen, Germany).

Statistics. Statistical comparisons were performed by ANOVA, followed by Fisher's protected least significant difference (PLSD) and Scheffé's $F$ test for comparison of significant difference among different means.

\section{Results}

Decreased ouabain-sensitive $\mathrm{Na}, \mathrm{K}$-ATPase activity in transgenic mutant SOD1 mice

Ouabain-sensitive Na,K-ATPase activity was measured in spinal cord tissue slice homogenates of transgenic mice expressing mutant or normal human SOD1 and wild-type controls. Because the assay is performed in vitro with saturating levels of ATP and ions, the measured activity reflects the maximal velocity of the enzyme itself and not ATP depletion secondary to mitochondrial damage in vivo. Figure $1 A$ shows that $\mathrm{Na}, \mathrm{K}-$ ATPase activity was decreased remarkably $(70-75 \%)$ in the severely impaired 4-month-old mutant SOD1 mice compared with nontransgenic animals. To determine whether the decreases were a result of the mutation or of overexpression of SOD1, we measured activity in samples from transgenic mice overexpressing normal human SOD1. There was a large but less dramatic decrease $(40-45 \%)$ in ouabain-sensitive Na,KATPase activity in the overexpressors. Immunoblot and densitometric analysis with a species-specific antibody for human SOD1 showed that the total level of exogenous SOD1, compared with a sample of purified enzyme, was not statistically different in mice overexpressing mutant and normal human SOD1 (Fig. $1 B, C$ ). The greater Na,K-ATPase activity loss in the mutant is consistent with "gain of function" consequences of excess SOD1 that are exacerbated by the mutation.

Cerebellum is not implicated in neurodegenerative processes in this ALS mouse model (Almer et al., 1999), but comparable losses in Na,K-ATPase activity also were seen in cerebellum in 
A

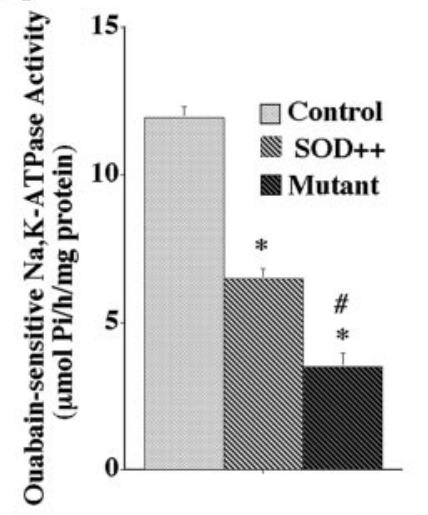

D

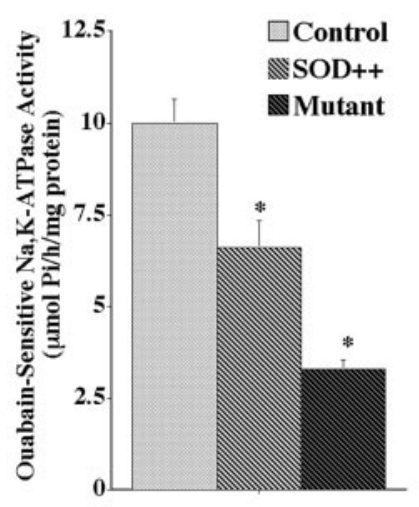

B
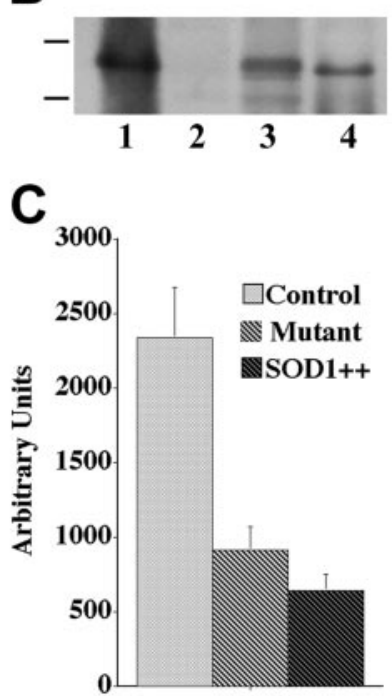

E

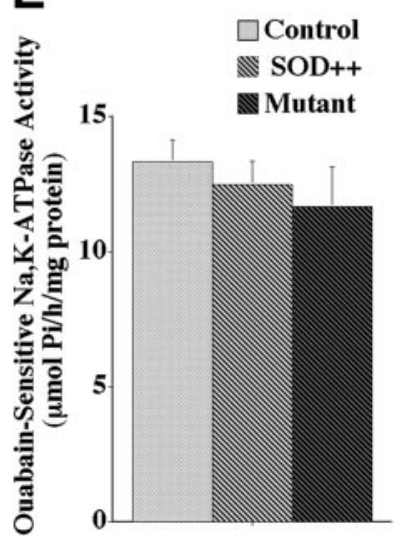

A

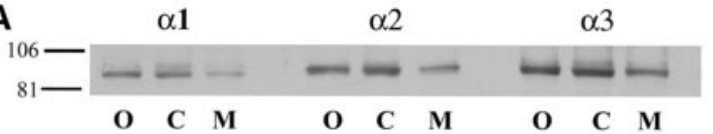

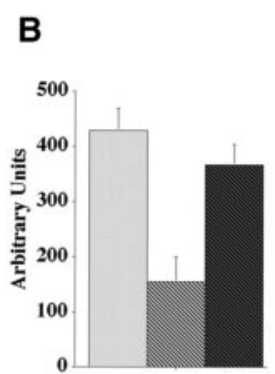

$\alpha 1$

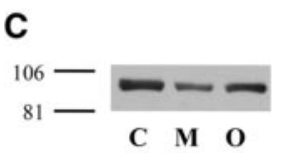

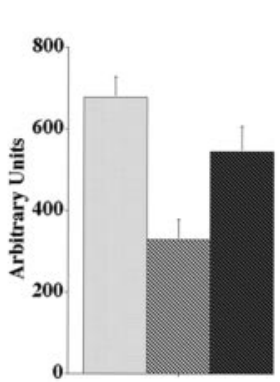

$\alpha 2$

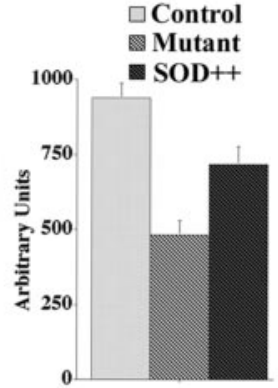

$\alpha 3$
E

$\beta 1$

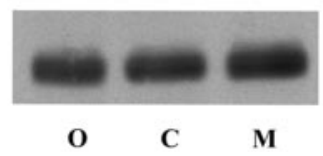

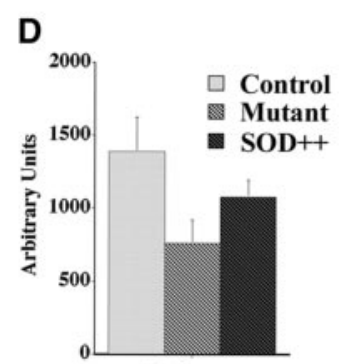

total $\alpha$

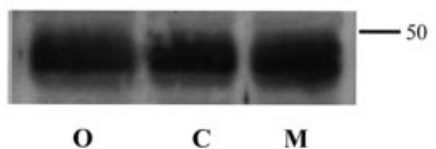

Figure 2. Immunoblot detection and quantitative analysis of $\mathrm{Na}$, K-ATPase isoforms in nontransgenic controls ( $C$, control), transgenic mutant SOD1 mice ( $M$, mutant) and transgenic normal human SOD1 overexpressors $(O, S O D++) . A, B$, Immunoblot and densitometric analysis of $\alpha 1, \alpha 2, \alpha 3$. For all immunoblots $50 \mu \mathrm{g}$ of spinal cord homogenates was used. $A$, Separated protein was stained with monoclonal antibodies to $\alpha 1$ (6F), $\alpha 2$ (McB2), and $\alpha 3$ (XVIF9G10). Crude homogenates from rat brain served as positive controls for the antibodies (data not shown). Molecular weight markers are shown in $\mathrm{kDa}$. B, Data are expressed as arbitrary units and represent the means \pm SEM for an average of three experiments. C, Immunoblot stained with KETYY, an antibody that recognizes all Na, K-ATPase $\alpha$ subunits. D, Densitometric analysis of KETYY expressed in arbitrary units and representing the means \pm SEM for an average of three experiments. E, Spinal cord homogenates were stained for $\beta 1$ (SpETb1) and $\beta 2$ (SpETb2) polyclonal antibodies. The data that are shown are representative of multiple experiments.

months of age, before the onset of obvious neurological symptoms.

\section{Decreased Na,K-ATPase $\alpha$ subunits in transgenic mutant SOD1 mice}

Losses in Na,K-ATPase activity could be attributable to enzyme inactivation, protein degradation, changes in gene expression, failure to transport newly synthesized protein to the axon, loss of neurons, or a combination of these. Quantitative detection of $\mathrm{Na}, \mathrm{K}-\mathrm{ATP}$ ase subunits makes it possible to assess whether protein levels were changed as much as activity. It also allows some conclusions to be made about whether the effect is on a particular $\mathrm{Na}, \mathrm{K}-\mathrm{ATPase}$ isoform or a particular cell type, because the $\alpha 3$ subunit is all in neurons and the myelinated axon tracts, whereas most of $\alpha 2$ is in astrocytes (Hieber et al., 1991; McGrail et al., 1991; Watts et al., 1991; Peng et al., 1997). The relative content of

$\mathrm{Na}$,K-ATPase $\alpha 1, \alpha 2$, and $\alpha 3$ subunits was determined in ho-

4-month-old animals (Fig. 1D). In agreement with Almer et al. (1999), we did not see any indication of major neuron loss in cerebellar tissue sections (data not shown). This is an initial indication that the losses of activity were not attributable simply to a loss of neurons. Figure $1 E$ shows that there were no significant reductions in Na,K-ATPase activity in spinal cord of transgenic mutant mice or transgenic overexpressors at 2 
Control

\section{Mutant}

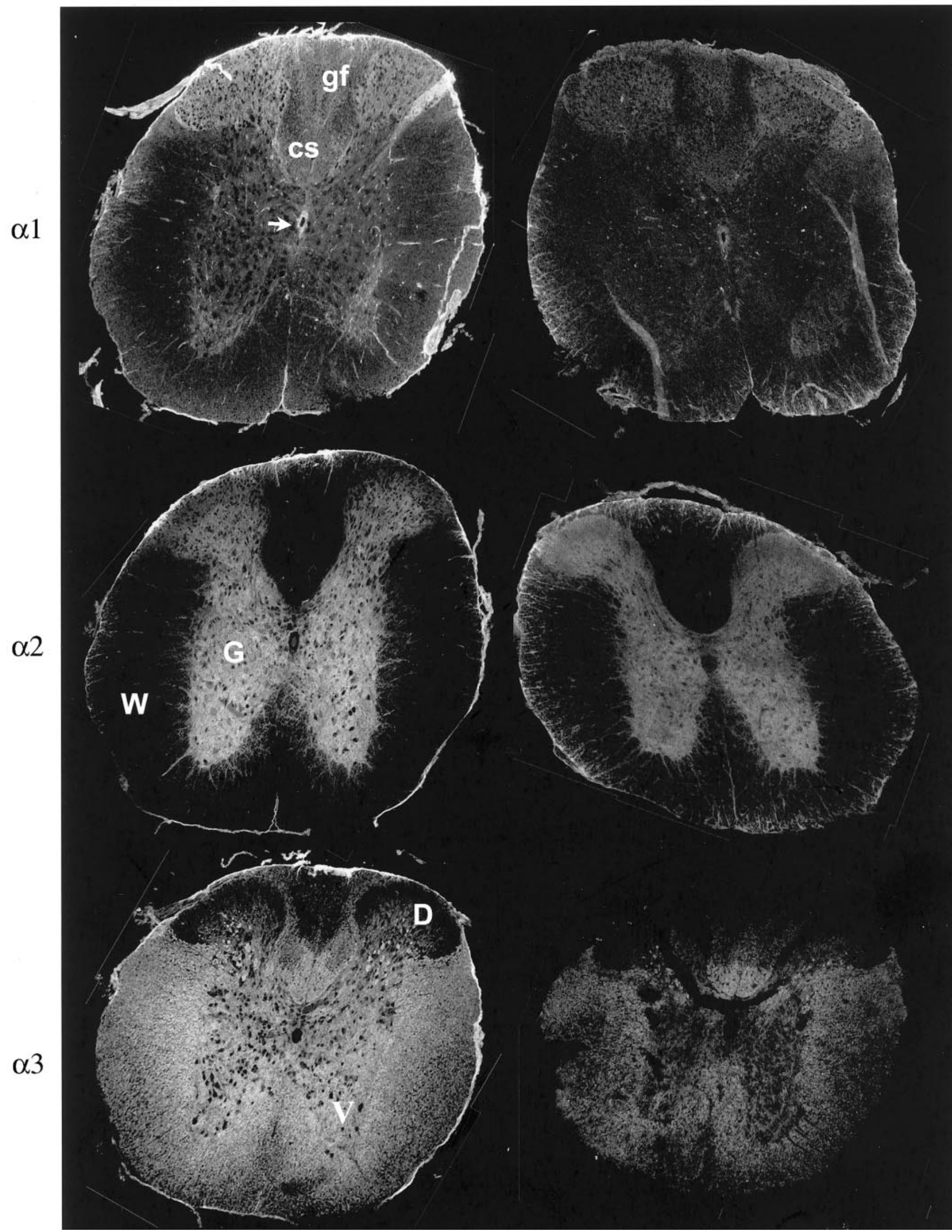


mogenates of spinal cord of transgenic mutant SOD1 mice, transgenic normal human SOD1 overexpressors, and nontransgenic controls by using isoform-specific monoclonal antibodies. Immunoblots (Fig. $2 \mathrm{~A}$ ) and densitometric analysis (Fig. $2 \mathrm{~B}$ ) showed that there were decreases in $\alpha 1$ (65\%), $\alpha 2$ (50\%), and $\alpha 3(50 \%)$ in transgenic mutant SOD1 mice compared with nontransgenic controls. Although there were also decreases in the three $\alpha$ isoforms in transgenic normal human SOD1 overexpressors, the decreases were smaller compared with transgenic mutant mice (Fig. 2 B). Total Na,K-ATPase $\alpha$ subunit level was quantified with a polyclonal antibody, anti-KETYY, that recognizes all $\mathrm{Na}, \mathrm{K}-$ ATPase isoforms. Figure 2, $C$ and $D$, shows that there were close to $50 \%$ decreases in total $\alpha$ protein in transgenic mutant SOD 1 mice when compared with nontransgenic controls and $20-25 \%$ decreases in normal SOD1 overexpressors. Isoform-specific antibodies for the $\beta 1$ and $\beta 2 \mathrm{Na}, \mathrm{K}$-ATPase subunits were used to examine $\beta$ levels. In contrast to the $\alpha$ subunit, no differences were detected in $\beta 1$ (mostly in neurons) or $\beta 2$ (mostly in astrocytes) in spinal cord samples from transgenic mutant SOD1, transgenic normal human SOD1 overexpressors, or nontransgenic control animals (Fig. 2E). $\beta 3$, which is found only in oligodendrocytes and at a low level (Martin-Vasallo et al., 2000), was not examined.

The reduction in Na,K-ATPase activity (Fig. $1 A$ ) exceeded the reduction in total $\mathrm{Na}, \mathrm{K}$-ATPase $\alpha$ subunit (Fig. $2 D$ ) in both mutant SOD1 mice and normal human SOD1 overexpressors by a substantial amount. Both measures were expressed per milligram of protein, and so the losses were over and above any generalized loss of tissue mass, which does occur with the loss of motor neurons. The greater loss of ATP hydrolysis than $\alpha$ subunit indicates that perturbations of SOD1 activity have an acute effect on $\mathrm{Na}, \mathrm{K}$ ATPase apart from any effect on gene expression, tissue or axon atrophy, or cell loss.

\section{$\mathrm{Na}, \mathrm{K}-\mathrm{ATPase}$ isoform distribution in normal and mutant spinal cord}

The distribution of the various $\mathrm{Na}, \mathrm{K}$-ATPase $\alpha$ subunits was determined by using confocal immunofluorescence with isoformspecific monoclonal antibodies. In the dorsal horn of the rat spinal cord some large neurons express both $\alpha 2$ and $\alpha 3$, whereas in the ventral horn some motor neurons express $\alpha 1$ and $\alpha 3$ and the rest just $\alpha 3$ (Mata et al., 1991; McGrail et al., 1991; Watts et al., 1991). In the mice that were investigated here, the pattern of staining for each $\alpha$ isoform was identical in sections from all levels of the spinal cord (cervical, thoracic, lumbar, and sacral; data not shown) except for the underlying structural differences in dorsal and ventral horns and axon tracts at different levels. Figure 3 shows immunostaining of tissue sections from the lumbar expansion of the spinal cord in 4-month-old nontransgenic controls and transgenic mutant SOD1 mice. In keeping with the plasma membrane location of the Na,K-ATPase, the cytoplasm of large-diameter neuronal cell bodies was unstained, although there were $\alpha 3$ ring-stained cell bodies in the central and lower regions of the dorsal horn. $\alpha 2$ stain characteristic of astrocytes was brightest in the gray matter, but it extended outward into the myelinated tracts accompanying radiating bundles of axons. It was notable that there were differences in the distribution of $\mathrm{Na}, \mathrm{K}-\mathrm{ATP}$ ase isoforms in wild-type mouse spinal cord that have

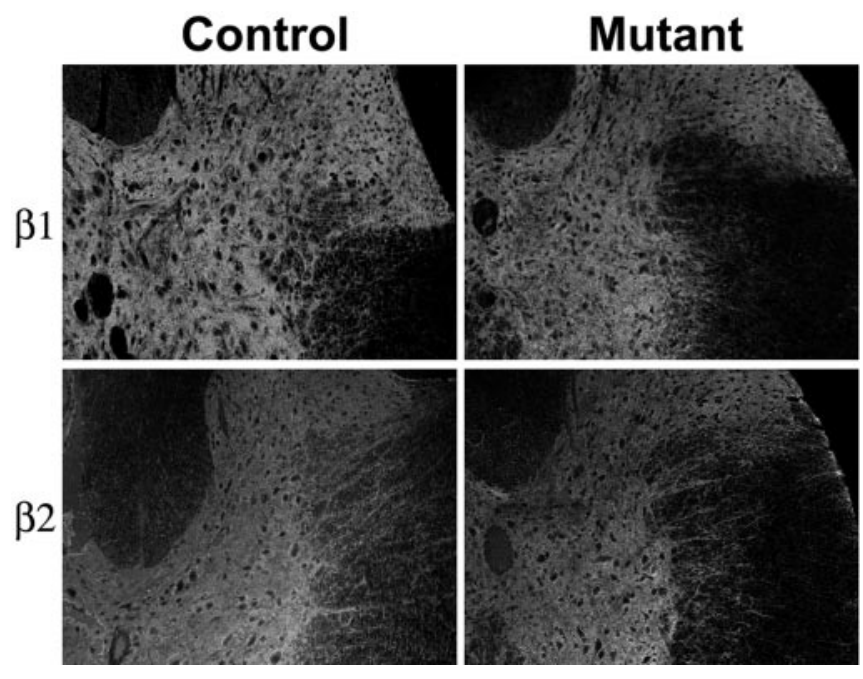

Figure 4. Immunodetection of Na,K-ATPase $\beta$ isoforms in nontransgenic controls and transgenic mutant SOD1 mice. Tissue sections were labeled with monoclonal antibodies to $\beta 1$ (BSP-3) and $\beta 2$ (426).

not been described before. The most striking was an apparent complementary difference in predominant $\alpha$ isoforms between dorsal and ventral horn. The parenchyma of dorsal horn stained most brightly for $\alpha 1$, whereas ventral horn stained most brightly for $\alpha 3$. The complementary difference also was observed for axons in the dorsal columns. The dorsal one-half of the dorsal column, the gracile fascicle that consists of ascending sensory axons, was enriched in $\alpha 1$, and the ventral one-half of the dorsal column, a descending corticospinal tract, was enriched in $\alpha 3$ as well as $\alpha 1$. These and the lateral $\alpha 3$-containing axon tracts are presumably the origin of the unidentified $\alpha 1$ - versus $\alpha 3$-containing myelinated tracts observed previously in the rat medulla (McGrail et al., 1991). In addition, the endothelial cells that line the central canal were stained brightly for $\alpha 1$, but not for $\alpha 2$ or $\alpha 3$, whereas the ensheathing pial membranes and fragments of dura mater stained for all three isoforms.

When they were compared with nontransgenic controls, there were markedly lower levels of staining for all three $\mathrm{Na}, \mathrm{K}$-ATPase $\alpha$ isoforms in transgenic mutant SOD1 animals (Fig. 3). If losses in $\mathrm{Na}, \mathrm{K}$-ATPase had been attributable to specific cell loss or to the atrophy of axons, the remaining cells would have more normal stain intensity. The uniformity of the loss of stain was the most notable feature, extending even to the ependymal lining of the central canal. The pial membranes, which appeared somewhat disrupted in the mutant mice, penetrated the white matter tracts more than they should, and their stain for $\alpha 3$ virtually was abolished.

In contrast, and consistent with the immunoblots shown above, staining patterns for $\beta 1$ and $\beta 2$ subunits were unaltered in the transgenic mutant SOD1 mice (Fig. 4). The principal difference that was seen was in the diffusely shrunken appearance of the pathological spinal cord. A lack of effect on $\beta$ expression suggests a lack of effect on $\mathrm{Na}, \mathrm{K}$-ATPase expression and biosynthesis, as discussed below.

Figure 3. Immunofluorescence detection of Na,K-ATPase isoforms in nontransgenic controls and transgenic mutant SOD1 mice. Tissue sections were labeled with monoclonal antibodies to $\alpha 1$ (6F), $\alpha 2$ (McB2), and $\alpha 3$ (XVIF9G10). Images were taken at $10 \times$, and montages were made to display the entire section. D, Dorsal horn; $G$, gray matter; W, white matter; $V$, ventral horn; $g f$, gracile fascicle of ascending sensory axons; cs, corticospinal tract. The arrow points to the ependyma lining the central canal. 


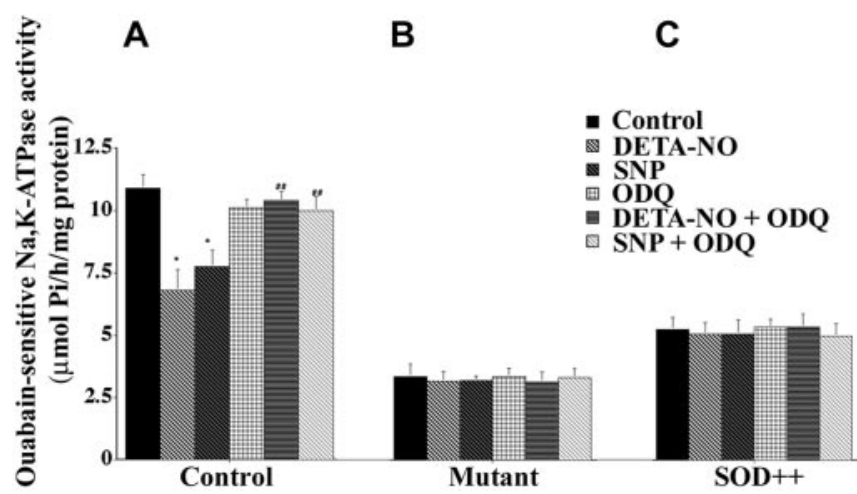

Figure 5. SNP- and DETA-NO-induced inhibition of ouabain-sensitive Na,K-ATPase was abolished in transgenic mutant SOD1 mice and transgenic normal human SOD1 overexpressors. Spinal cord tissue slices were incubated with or without $\mathrm{ODQ}(1 \mu \mathrm{M})$ for $3 \mathrm{~min}$ at $34^{\circ} \mathrm{C}$, followed by incubation with DETA-NO $(100 \mu \mathrm{m})$ or SNP $(100 \mu \mathrm{m})$ for 15 min at $34^{\circ} \mathrm{C}$. Drugs were removed, tissue slices were homogenized, and ouabain-sensitive $\mathrm{Na}, \mathrm{K}$-ATPase activity was measured. For all graphs that are shown, activity is expressed as $\mu \mathrm{mol} \mathrm{P}_{\mathrm{i}} / \mathrm{hr}$ per milligram of protein, and values represent the means \pm SEM for experiments on three animals done in triplicate. $A$, Ouabain-sensitive Na,K-ATPase activity in nontransgenic controls. * Significantly different from the control at $p<0.05$ (by ANOVA and Fisher's PLSD). "\# Significantly different from DETA-NOand SNP-treated samples at $p<0.05$ (by ANOVA and Fisher's PLSD). B, C, Ouabain-sensitive $\mathrm{Na}, \mathrm{K}-$ ATPase activity in transgenic mutant SOD1 and transgenic SOD1 normal human SOD1 overexpressors.

$\mathrm{NO}$ is unable to regulate $\mathrm{Na}, \mathrm{K}$-ATPase activity in spinal cord of transgenic mice

In some tissues $\mathrm{NO}$ is a normal $\mathrm{Na}, \mathrm{K}-\mathrm{ATPase}$ regulator acting through cGMP. Because free radical homeostasis appears to be perturbed in some forms of ALS, we tested whether regulation of the $\mathrm{Na}, \mathrm{K}-\mathrm{ATPase}$ was affected in this model. Spinal cord tissue slices from nontransgenic control mice were exposed to the NO donors SNP (Garthwaite et al., 1995) and DETA-NO (Diodati et al., 1993) for $15 \mathrm{~min}$. Both donors caused a marked reduction (35-45\%) of ouabain-sensitive Na,K-ATPase activity (Fig. 5A). The effects were specific to $\mathrm{Na}, \mathrm{K}$-ATPase, because no measurable changes were observed in the ouabain-insensitive (Mg-ATPase) activity (data not shown). Many of the physiological actions of $\mathrm{NO}$ on Na,K-ATPase activity involve activation of soluble guanylate cyclase (McKee et al., 1994; Nathanson et al., 1995; Scavone et al., 1995; Ellis et al., 2000, 2001). When SNP- or DETA-NOtreated spinal cord tissue slices were exposed to ODQ, an inhibitor selective for soluble guanylate cyclase (Garthwaite et al., 1995), it primarily blocked the SNP- and DETA-NO-induced inhibition of ouabain-sensitive Na,K-ATPase activity (Fig. 5A).

The effects of NO donors on activity in tissue slices from spinal cord of transgenic mutant SOD1 mice and of transgenic normal human SOD1 overexpressors are shown in Figure 5, $B$ and $C$. The basal Na,K-ATPase activity was low, and neither SNP nor DETA-NO further inhibited it. The addition of ODQ in the presence of SNP or DETA-NO, or alone, failed to alter ouabainsensitive $\mathrm{Na}$,K-ATPase activity in spinal cord tissue slices of transgenic mutant SOD1 mice (Fig. $5 B$ ) or transgenic normal human SOD1 overexpressors (Fig. 5 C). Because ODQ treatment did not restore the lost activity, the data argue against a high basal level of otherwise-normal NO-mediated regulation as the cause of $\mathrm{Na}, \mathrm{K}-\mathrm{ATP}$ ase inhibition in the transgenic mice. These results indicate a surprisingly complete perturbation, in normal SOD1 overexpressors as well as mutants, of a regulatory pathway that in physiological conditions depends on the diffusion of NO from its site of synthesis to soluble guanylate cyclase.

The ability of NO donors to increase levels of cGMP by acti-

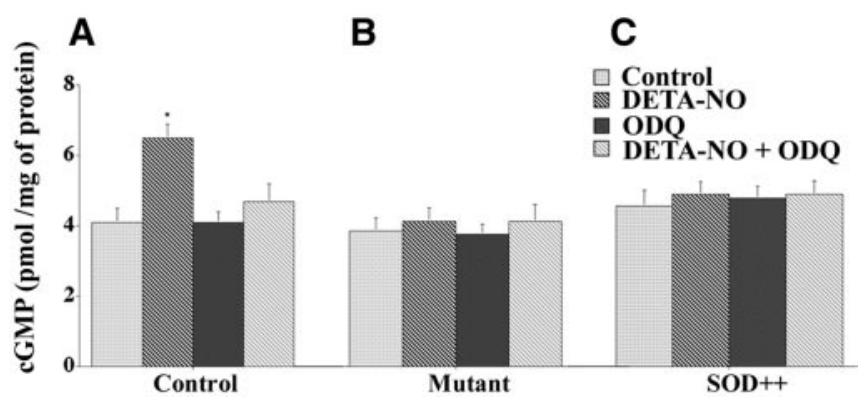

Figure 6. CGMP levels are unaltered in transgenic SOD1 mice in response to DETA-NO treatment. Spinal cord tissue slices from nontransgenic controls $(A)$, transgenic mutant SOD1 mice $(B)$, or transgenic normal human SOD1 overexpressors $(C)$ were incubated for 3 min at $34^{\circ} \mathrm{C}$ with ODQ $(1 \mu \mathrm{m})$, followed by incubation for $15 \mathrm{~min}$ at $34^{\circ} \mathrm{C}$ with DETA-NO $(100 \mu \mathrm{M})$. After centrifugation the supernatant was removed and assayed for CGMP, expressed as $\mathrm{pmol} / \mathrm{mg}$ protein. * Significantly different from the control group at $p<0.05$ (by ANOVA, Fisher's PLSD, and Scheffé's F test). Values for cGMP levels represent the means \pm SEM for three experiments.

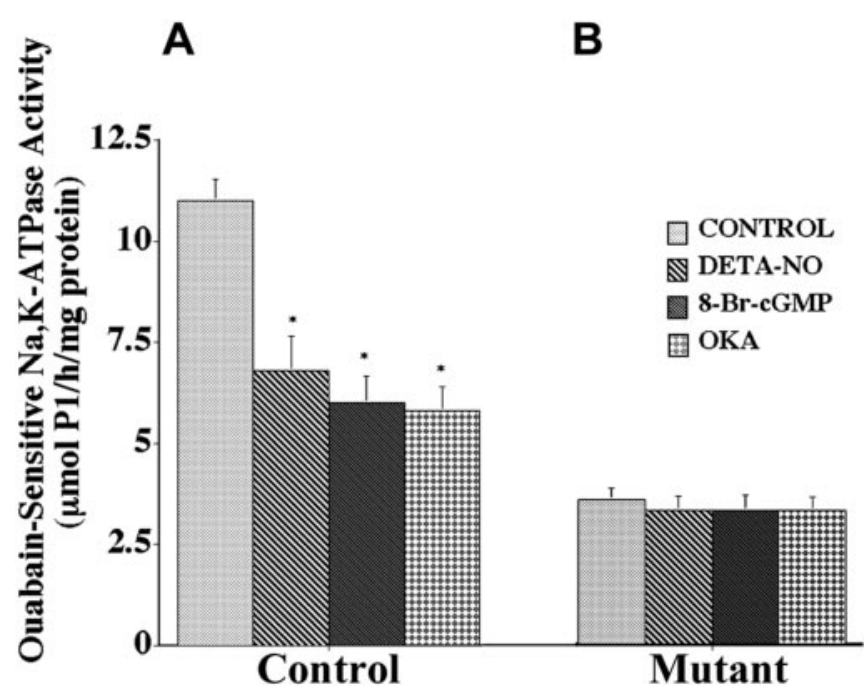

Figure 7. Ouabain-sensitive $\mathrm{Na}^{+}, \mathrm{K}$-ATPase activity in spinal cord of nontransgenic control mice $(A)$ and transgenic mutant SOD1 mice $(B)$ after incubation with DETA-NO $(100 \mu \mathrm{M})$, 8-Br-CGMP (2 mM), or okadaic acid (OKA; $400 \mathrm{nM})$. Results are expressed as $\mu \mathrm{mol} \mathrm{P}_{\mathrm{i}} / \mathrm{hr}$ per milligram of protein, and values represent the means \pm SEM for three animals done in triplicate. *Significantly different from the control at $p<0.05$ (by ANOVA and Fisher's PLSD).

vating soluble guanylate cyclase was tested in the three groups of mice. In nontransgenic control mice the addition of DETA-NO to spinal cord tissue slices caused a $40 \%$ increase in cGMP levels that, as expected, was abolished by the guanylate cyclase inhibitor ODQ (Fig. 6A). In contrast, there were no measurable changes in cGMP levels in either transgenic mutant SOD1 mice or transgenic normal human SOD1 overexpressors treated with DETANO, ODQ, or DETA-NO plus ODQ (Fig. 6B,C). This could mean that soluble guanylate cyclase, like Na,K-ATPase, is inactivated in these mice, possibly targeted by its specific binding site for a free radical, although such losses were not reported in the G1L strain of G93A mice, which expresses mutant SOD1 at a lower level (Facchinetti et al., 1999). Alternatively, the NO generated by the artificial donors could be consumed rapidly in reactions catalyzed by the aberrant elevated levels of SOD1.

The pathway downstream of guanylate cyclase was tested by exposure of spinal cord tissue slices to the permeable protein kinase G activator, 8-Br-cGMP. Figure 7A shows that in nontransgenic controls this caused an inhibition of $\mathrm{Na}$,K-ATPase activity as effective as DETA-NO treatment. However, there were 
no changes in activity in tissue from transgenic mutant SOD1 mice (Fig. $7 B$ ). Evidence for the involvement of protein phosphorylation in mediating the normal $\mathrm{NO}$-induced regulation of $\mathrm{Na}, \mathrm{K}-\mathrm{ATP}$ ase activity is shown in Figure 7 also. The addition of okadaic acid ( $400 \mathrm{~nm}$ ) at concentrations known to inhibit protein phosphatases type 1 and type $2 \mathrm{~A}$ mimicked the effects of DETA-NO and 8-Br-cGMP in inhibiting ouabain-sensitive $\mathrm{Na}, \mathrm{K}-\mathrm{ATP}$ ase activity in nontransgenic SOD1 controls (Fig. 7A). Okadaic acid had no effect, however, on transgenic mutant SOD1 mice (Fig. $7 B$ ). The inability to bypass any step of the NOmediated regulatory pathway is evidence either for the broadly compromised state of the transgenic spinal cord or for the resistance of the residual $\mathrm{Na}, \mathrm{K}-\mathrm{ATPa} e$ activity to any further regulation.

\section{Discussion}

The mechanisms of motor neuron death in ALS are unknown, but several theories have been proposed, including that mutations in SOD1 may result in oxidative stress (Beckman et al., 1993; Crow et al., 1997; Andrus et al., 1998), increases in NO synthase and reactivity of astrocytes (Almer et al., 1999), and glutamate excitotoxicity secondary to glutamate transporter defects (Rothstein et al., 1993; Bruijn et al., 1997; Trotti et al., 1999). Other possible causes of neuronal degeneration include alterations in mitochondrial function (Beal, 1995; Klivenyi et al., 1999), formation of mutant SOD1 protein aggregates (Bruijn et al., 1998), and improper assembly of intermediate filaments that have particular impact on motor neurons because of their exceptionally long axons (for review, see Cleveland and Rothstein, 2001; Julien, 2001). Although all of these may contribute to the pathology and some may determine the selective vulnerability of motor neurons, perturbation of free radical homeostasis directly related to the SOD1 mutation is the phenomenon that is least likely to be secondary to the neurodegeneration process. Curiously, selective expression of mutant SOD1 in either astrocytes or neurons alone has failed to induce the disease (Gong et al., 2000; Pramatarova et al., 2001; Lino et al., 2002).

\section{Uniform loss of Na,K-ATPase}

These studies demonstrate that there are surprisingly large decreases in ouabain-sensitive Na,K-ATPase in spinal cord of transgenic mutant SOD1 mice, as assessed by enzyme activity, $\alpha$ subunit content, and anatomical distribution. Because of the uniformity, the losses are not likely to be a secondary consequence of neuron atrophy or death; this was confirmed by the observation of similar losses of $\mathrm{Na}, \mathrm{K}-\mathrm{ATP}$ ase in the cerebellum. There were less severe decreases in Na,K-ATPase in the mice overexpressing transgenic normal human SOD1. SOD1 overexpression, which occurs in Down's syndrome as a direct result of trisomy, also is thought to increase oxidative damage (CeballosPicot et al., 1991; Lee et al., 2001), exacerbate excitotoxicity (BarPeled et al., 1996), and affect hippocampal ultrastructure and function (Barkats et al., 1993; Gahtan et al., 1998). Because the transgenic normal human SOD1 mice we used do not show hallmarks of ALS pathology such as SOD1 aggregates, intermediate filament aggregates, and mitochondrial defects, the observed $\mathrm{Na}, \mathrm{K}-\mathrm{ATP}$ ase losses are more likely to be attributable to a "gain of function" abnormality of free radical or oxidant homeostasis than to ALS-associated neurodegeneration. These findings suggest that decreased Na,K-ATPase activity contributes to SOD1 ALS via inactivation and the loss of all three $\alpha$ subunits.

Any given cell type expresses a particular combination of $\alpha$ and $\beta$ subunits (McGrail et al., 1991; Watts et al., 1991; Peng et al.,
1997; Wetzel et al., 1999; Martin-Vasallo et al., 2000). Many neurons, for example, express $\alpha 3 \beta 1$, mature astrocytes express $\alpha 2 \beta 2$, and oligodendrocytes express $\alpha 2 \beta 3$, but there are exceptions, such as the granule neurons of the cerebellum that express $\alpha 3 \beta 2$, Müller glial cells that express $\alpha 1 \beta 2$, and neurons that express more than one assembled complex. Decreases in $\alpha 3$ are diagnostic for neuronal defects, because this isoform is not expressed in glia. Decreases in $\alpha 2$ are additional evidence that astrocytes as well as neurons are affected in the disease. Two well established functions of glia are the clearance of potassium and the $\mathrm{Na}^{+}$dependent uptake of glutamate from the extracellular space after synaptic activation. $\mathrm{Na}, \mathrm{K}-\mathrm{ATP}$ ase is activated when $\left[\mathrm{Na}^{+}\right]_{\mathrm{i}}$ rises concomitantly with glutamate uptake (Rose and Ransom, 1996), and this stimulates the uptake of $\mathrm{K}^{+}$. The importance of these observations to ALS is highlighted by reports of selective loss of the astrocyte-specific glutamate transporter EAAT2 (GLT-1) (Rothstein et al., 1995) and of its vulnerability to oxidation by certain mutant SOD1 forms (Trotti et al., 1999). A defect in the glutamate transporter, a defect in the underlying glial sodium pump activity, and a defect in Na,K-ATPase activity in the neurons themselves are compatible with previous proposals that excitotoxicity contributes to the progression of ALS.

Detection of the simultaneous loss of Na,K-ATPase $\alpha$ isoforms specific to all different cell types in the spinal cord paints a compelling picture of a defect that is not confined to the motor neurons that die, however. The implications of the diffuse nature of the $\mathrm{Na}, \mathrm{K}$-ATPase alterations are potentially far-reaching. It suggests, for one thing, that the mutant mice have a "sick cord" and that studies of almost any candidate protein could reveal alterations that may contribute to the final pathology. It also suggests that alterations in the barrier organs such as the ependyma and pia may contribute to the disease. The loss of one-half to three-quarters of the enzyme that is the largest consumer of ATP may help to offset the effects of mitochondrial pathology and suggests that further investigation of energy metabolism in ALS would be fruitful (Browne et al., 1998; Klivenyi et al., 1999; Ames, 2000).

\section{Altered free radical homeostasis and regulation of Na,K-ATPase}

The NO/soluble guanylate cyclase pathway was altered severely in both transgenic mutant human SOD1 mice and transgenic normal human SOD1 overexpressors, whereas it inhibited ouabainsensitive $\mathrm{Na}, \mathrm{K}-\mathrm{ATP}$ ase activity in nontransgenic control mice. $\mathrm{NO}$-mediated regulation of $\mathrm{Na}, \mathrm{K}$-ATPase activity is known in other tissues, including ciliary process and choroid plexus (Ellis et al., 2000, 2001). In the CNS, NO modulates cerebral blood flow and synaptic transmission via the activation of soluble guanylate cyclase and increases in cGMP (Murad, 1998). The loss of NO regulation in transgenic mutant SOD1 mice might have been predicted, considering the severity of the illness. However, the total blockade of the NO/cGMP pathway for Na,K-ATPase regulation in transgenic normal SOD1 overexpressors was unexpected.

The role of NO in CNS-related diseases is not completely clear. Several lines of evidence have emerged that suggest that $\mathrm{NO}$ can be either neuroprotective (Lipton et al., 1993; Chiueh, 1999) or neurodestructive (Dawson et al., 1991, 1992; Samdani et al., 1997). NO generated from NO donors or synthesized endogenously after activation of the ionotropic glutamate receptor (Lafon-Cazal et al., 1993) can lead to neurotoxicity in part by reaction with superoxide anion and the subsequent formation of peroxynitrite (Lipton et al., 1993; Beckman and Koppenol, 1996). 
In contrast, other studies have demonstrated that the neuroprotective effects of NO in CNS may result from nitration or nitrosylation of iron- or thiol-containing proteins (Stamler et al., 1992; Lipton et al., 1993; Chiueh, 1999). Such chemical modifications may alter significantly the biological activity of the protein and minimize the generation of reactive oxygen species and associated oxidative stress. A lack of effect on ALS pathology when G93A mice were crossed with neuronal nitric oxide synthase (nNOS) knock-out mice suggested no involvement, but residual nNOS activity because of the synthesis of truncated forms complicated the interpretation (Facchinetti et al., 1999).

The degree of inhibition of Na,K-ATPase activity in transgenic mutant mice exceeded the decrease in the $\alpha$ subunit. The $\mathrm{Na}, \mathrm{K}-\mathrm{ATP}$ ase can be inhibited chemically by oxygen free radicals and their by-products (Mense et al., 1997). For example, superoxide anion, hydrogen peroxide, and hydroxyl radicals inhibited $\mathrm{Na}, \mathrm{K}-\mathrm{ATP}$ ase activity, and this decrease correlated with increased lipid peroxidation (Viani et al., 1991; Huang et al., 1992). Of interest is the finding that various NO donors (excluding sodium nitroprusside) caused substantial direct alterations in $\mathrm{Na}, \mathrm{K}$ ATPase activity via reaction with free sulfhydryl groups (Boldyrev et al., 1997; Sato et al., 1997). Furthermore, as with other proteins (Stadtman, 1992), exposure of the Na,K-ATPase to free radicals made it more susceptible to degradation by proteolytic enzymes (Huang et al., 1992; Thevenod and Friedmann, 1999). Because $\alpha$ and $\beta$ subunits normally are found in a 1:1 ratio, the reduction in $\alpha$, but not $\beta$, was unexpected. The data are consistent with greater vulnerability of the $\alpha$ subunit to damage and degradation. This is plausible, considering that the majority of the mass of the $\beta$ subunit is in the extracellular space where it is adapted to a more oxidizing environment than the cytoplasm, and that its six extracellular sulfhydryl groups are all in buried disulfide bonds. Most of the mass of the $\alpha$ subunit, in contrast, is in the reducing environment on the cytoplasmic side of the membrane, and it has 23 free sulfhydryls and other oxidizable groups.

The widespread defects in Na,K-ATPase, not confined to either neurons or glia, support the original hypothesis that perturbation of free radical homeostasis is the most likely root cause of mutant SOD1 ALS pathology. The abrogation of the NO/cGMP pathway of $\mathrm{Na}, \mathrm{K}-\mathrm{ATPa} e$ regulation is an unexpected and potentially important event, whether it is a parallel defect with the same root cause or a causative step in $\mathrm{Na}, \mathrm{K}$-ATPase loss.

\section{References}

Almer G, Vukosavic S, Romero N, Przedborski S (1999) Inducible nitric oxide synthase up-regulation in a transgenic mouse model of familial amyotrophic lateral sclerosis. J Neurochem 72:2415-2425.

Ames III A (2000) CNS energy metabolism as related to function. Brain Res Brain Res Rev 34:42-68.

Andrus PK, Fleck TJ, Gurney ME, Hall ED (1998) Protein oxidative damage in a transgenic mouse model of familial amyotrophic lateral sclerosis. J Neurochem 71:2041-2048.

Barkats M, Bertholet J-Y, Venault P, Ceballos-Picot I, Nicole A, Phillips J, Moutier R, Roubertoux P, Sinet PM, Cohen-Salmon M (1993) Hippocampal mossy fiber changes in mice transgenic for the human copper/ zinc superoxide dismutase gene. Neurosci Lett 160:24-28.

Bar-Peled O, Korkotian E, Segal M, Groner Y (1996) Constitutive overexpression of $\mathrm{Cu} / \mathrm{Zn}$ superoxide dismutase exacerbates kainic acid-induced apoptosis of transgenic $\mathrm{Cu} / \mathrm{Zn}$ superoxide dismutase neurons. Proc Natl Acad Sci USA 93:8530-8535.

Beal MF (1995) Aging, energy, and oxidative stress in neurodegenerative diseases. Ann Neurol 38:357-366.

Beckman JS, Koppenol WH (1996) Nitric oxide, superoxide, and peroxynitrite: the good, the bad, and the ugly. Am J Physiol 271:C1424-C1437.

Beckman JS, Carson M, Smith CD, Koppenol WH (1993) ALS, SOD, and peroxynitrite. Nature 364:584.
Blanco G, Mercer RW (1998) Isozymes of the Na-K-ATPase: heterogeneity in structure, diversity in function. Am J Physiol 275:F633-F650.

Boldyrev AA, Bulygina ER, Kramarenko GG, Vanin AF (1997) Effect of nitroso compounds on Na/K-ATPase. Biochim Biophys Acta 1321:243-251.

Brines ML, Robbins RJ (1992) Inhibition of $\alpha 2 / \alpha 3$ sodium pump isoforms potentiates glutamate neurotoxicity. Brain Res 591:94-102.

Brines ML, Dare AO, de Lanerolle NC (1995) The cardiac glycoside ouabain potentiates excitotoxic injury of adult neurons in rat hippocampus. Neurosci Lett 191:145-148.

Brown Jr RH (1995) Amyotrophic lateral sclerosis: recent insights from genetics and transgenic mice. Cell 80:687-692.

Browne SE, Bowling AC, Baik MJ, Gurney ME, Brown Jr RH, Beal MF (1998) Metabolic dysfunction in familial, but not sporadic, amyotrophic lateral sclerosis. J Neurochem 71:281-287.

Bruijn LI, Becher MW, Lee MK, Anderson KL, Jenkins NA, Copeland NG, Sisodia SS, Rothstein JD, Borchelt DR, Price DL, Cleveland DW (1997) ALS-linked SOD1 mutant G85R mediates damage to astrocytes and promotes rapidly progressive disease with SOD1-containing inclusions. Neuron 18:327-338.

Bruijn LI, Houseweart MK, Kato S, Anderson KL, Anderson SD, Ohama E, Reaume AG, Scott RW, Cleveland DW (1998) Aggregation and motor neuron toxicity of an ALS-linked SOD1 mutant independent from wildtype SOD1. Science 281:1851-1854.

Calabresi P, De Murtas M, Pisani A, Stefani A, Sancesario G, Mercuri NB, Bernardi G (1995) Vulnerability of medium spiny striatal neurons to glutamate: role of $\mathrm{Na}^{+} / \mathrm{K}^{+}$-ATPase. Eur J Neurosci 7:1674-1683.

Ceballos-Picot I, Nicole A, Briand P, Grimber G, Delacourte A, Defossez A, Javoy-Agid F, Lafon M, Blouin JL, Sinet PM (1991) Neuronal-specific expression of human copper/zinc superoxide dismutase gene in transgenic mice: animal model of gene dosage effects in Down's syndrome. Brain Res 552:198-214.

Chiueh CC (1999) Neuroprotective properties of nitric oxide. Ann NY Acad Sci 890:301-311.

Cleveland DW, Rothstein JD (2001) From Charcot to Lou Gehrig: deciphering selective motor neuron death in ALS. Nat Rev Neurosci 2:806-819.

Crambert G, Hasler U, Beggah AT, Yu C, Modyanov NN, Horisberger J-D, Lelievre L, Geering K (2000) Transport and pharmacological properties of nine different human Na,K-ATPase isozymes. J Biol Chem 275:1976-1986.

Crow JP, Sampson JB, Zhuang Y, Thompson JA, Beckman JS (1997) Decreased zinc affinity of amyotrophic lateral sclerosis-associated superoxide dismutase mutants leads to enhanced catalysis of tyrosine nitration of peroxynitrite. J Neurochem 69:1936-1944.

Dawson TM, Dawson VL, Snyder SH (1992) A novel neuronal messenger molecule in brain: the free radical, nitric oxide. Ann Neurol 32:297-311.

Dawson VL, Dawson TM, London ED, Bredt DS, Snyder SH (1991) Nitric oxide mediates glutamate neurotoxicity in primary cortical cultures. Proc Natl Acad Sci USA 88:6368-6371.

Diodati JG, Quyyumi AA, Keefer LK (1993) Complexes of nitric oxide with nucleophiles as agents for the controlled biological release of nitric oxide: hemodynamic effects in rabbit. J Cardiovasc Pharmacol 22:287-292.

Ellis DZ, Nathanson JA, Sweadner KJ (2000) Carbachol inhibits $\mathrm{Na}^{+}-\mathrm{K}^{+}$ATPase activity in choroid plexus via stimulation of the NO/cGMP pathway. Am J Physiol 279:C1685-C1693.

Ellis DZ, Nathanson JA, Rabe J, Sweadner KJ (2001) Carbachol and NO inhibit $\mathrm{Na}, \mathrm{K}-\mathrm{ATP}$ ase in ciliary process via activation of guanylate cyclase and cGMP. Invest Ophthalmol Vis Sci 42:2625-2631.

Facchinetti F, Sasaki M, Cutting FB, Zhai P, MacDonald JE, Reif D, Beal MF, Huang PL, Dawson TM, Gurney ME, Dawson VL (1999) Lack of involvement of neuronal nitric oxide synthase in the pathogenesis of a transgenic mouse model of familial amyotrophic lateral sclerosis. Neuroscience 90:1483-1492.

Gahtan E, Auerbach JM, Groner Y, Segal M (1998) Reversible impairment of long-term potentiation in transgenic $\mathrm{Cu} / \mathrm{Zn}$ SOD mice. Eur J Neurosci 10:538-544.

Garthwaite J, Southam E, Boulton CL, Nielsen EB, Schmidt K, Mayer B (1995) Potent and selective inhibition of nitric oxide-sensitive guanylyl cyclase by ${ }^{1} \mathrm{H}$-[1,2,4] oxadiazolo[4,3-a] quinoxalin-1-one. Mol Pharmacol 48:184-188.

Gong YH, Parsadanian AS, Andreeva A, Snider WD, Elliott JL (2000) Restricted expression of $\mathrm{G} 86 \mathrm{R} \mathrm{Cu} / \mathrm{Zn}$ superoxide dismutase in astrocytes 
results in astrocytosis but does not cause motoneuron degeneration. J Neurosci 20:660-665.

Gurney ME, Pu H, Chiu AY, Dal Canto MC, Polchow CY, Alexander DD, Caliendo J, Hentati A, Kwon YW, Deng H-X, Chen W, Zhai P, Sufit L, Siddique T (1994) Motor neuron degeneration in mice that express a human $\mathrm{Cu} / \mathrm{Zn}$ superoxide dismutase mutation. Science 264:1772-1775.

Hieber V, Siegel GJ, Fink DJ, Beaty MW, Mata M (1991) Differential distribution of $(\mathrm{Na}, \mathrm{K})$-ATPase $\alpha$ isoforms in the central nervous system. Cell Mol Neurobiol 11:253-262.

Huang WH, Wang Y, Askari A (1992) $\left(\mathrm{Na}^{+}+\mathrm{K}^{+}\right)$-ATPase: inactivation and degradation induced by oxygen radicals. Int J Biochem 24:621-626.

Julien J-P (2001) Amyotrophic lateral sclerosis: unfolding the toxicity of the misfolded. Cell 104:581-591.

Kim MS, Akera T (1987) $\mathrm{O}_{2}$ free radicals: cause of ischemia-reperfusion injury to cardiac $\mathrm{Na}^{+}, \mathrm{K}^{+}$-ATPase. Am J Physiol 252:H252-H257.

Klivenyi P, Ferrante RJ, Matthews RT, Bogdanov MB, Klein AM, Andreassen OA, Mueller G, Wermer M, Kaddurah-Daowk R, Beal MF (1999) Neuroprotective effects of creatine in a transgenic animal model of amyotrophic lateral sclerosis. Nat Med 3:347-350.

Lafon-Cazal M, Pietri S, Culcasi M, Bockaert J (1993) NMDA-dependent superoxide production and neurotoxicity. Nature 364:535-537.

Lee M, Hyun D-H, Jenner P, Halliwill B (2001) Effect of overexpression of wild-type and mutant $\mathrm{Cu} / \mathrm{Zn}$ superoxide dismutases on oxidative damage and antioxidant defenses: relevance to Down's syndrome and familial amyotrophic lateral sclerosis. J Neurochem 76:957-965.

Lees GJ, Leong W (1996) Interactions between excitotoxins and the $\mathrm{Na}^{+}, \mathrm{K}^{+}$-ATPase inhibitor ouabain in causing neuronal lesions in the rat hippocampus. Brain Res 714:145-155.

Lees GJ, Lehmann A, Sandberg M, Hamberger A (1990) The neurotoxicity of ouabain, a sodium/potassium ATPase inhibitor, in the rat hippocampus. Neurosci Lett 120:159-162.

Lino MM, Schneider C, Caroni P (2002) Accumulation of SOD1 mutants in postnatal motoneurons does not cause motoneuron pathology or motoneuron disease. J Neurosci 22:4825-4832.

Lipton SA, Choi Y-B, Pan Z-H, Lei SZ, Chen H-S, Sucher NJ, Loscalzo J, Singel DJ, Stamler JS (1993) A redox-based mechanism for the neuroprotective and neurodestructive effects of nitric oxide and related nitroso compounds. Nature 364:626-632.

Martin-Vasallo P, Wetzel RK, Garcia-Segura LM, Molina-Holgado E, Arystarkhova E, Sweadner KJ (2000) Oligodendrocytes in brain and optic nerve express the $\beta 3$ subunit isoform of $\mathrm{Na}, \mathrm{K}-\mathrm{ATP}$ ase. Glia 31:206-218.

Mata M, Siegel GJ, Hieber V, Beaty MW, Fink DJ (1991) Differential distribution of $(\mathrm{Na}, \mathrm{K})$-ATPase $\alpha$ isoform mRNAs in the peripheral nervous system. Brain Res 546:47-54.

McGrail KM, Phillips JM, Sweadner KJ (1991) Immunofluorescent localization of three $\mathrm{Na}$, K-ATPase isozymes in the rat central nervous system: both neurons and glia can express more than one Na,K-ATPase. J Neurosci 11:381-391.

McKee M, Scavone C, Nathanson JA (1994) Nitric oxide, cGMP, and hormone regulation of active sodium transport. Proc Natl Acad Sci USA 91:12056-12060.

McLean IW, Nakane PK (1974) Periodate-lysine-paraformaldehyde fixative. A new fixative for immunoelectron microscopy. J Histochem Cytochem 22:1077-1083.

Mense M, Stark G, Apell H-J (1997) Effects of free radicals on partial reactions of the Na,K-ATPase. J Membr Biol 156:63-71.

Murad F (1998) Nitric oxide signaling: would you believe that a simple free radical could be a second messenger, autacoid, paracrine substance, neurotransmitter, and hormone? Recent Prog Horm Res 53:43-59.

Nathanson JA, Scavone C, Scanlon C, McKee M (1995) The cellular $\mathrm{Na}^{+}$ pump as a site of action for carbon monoxide and glutamate: a mechanism for long-term modulation of cellular activity. Neuron 14:781-794.

Peng L, Martin-Vasallo P, Sweadner KJ (1997) Isoforms of Na,K-ATPase $\alpha$ and $\beta$ subunits in the rat cerebellum and in granule cell cultures. J Neurosci 17:3488-3502.

Pramatarova A, Laganiere J, Roussel J, Brisebois K, Rouleau GA (2001) Neuron-specific expression of mutant superoxide dismutase 1 in transgenic mice does not lead to motor impairment. J Neurosci 21:3369-3374.

Rose CR, Ransom BR (1996) Mechanisms of $\mathrm{H}^{+}$and $\mathrm{Na}^{+}$changes induced by glutamate, kainate, and $\mathrm{D}$-aspartate in rat hippocampal astrocytes. J Neurosci 16:5393-5404.

Rosen DR, Siddique T, Patterson D, Figlewicz DA, Sapp P, Hentati A, Donaldson D, Goto J, O’Regan JP, Deng HX, Gusella JS, Horvitz HR, Brown Jr RH (1993) Mutations in Cu/Zn superoxide dismutase gene are associated with familial amyotrophic lateral sclerosis. Nature 362:59-62.

Rothstein JD, Jin L, Dykes-Hoberg M, Kuncl RW (1993) Chronic inhibition of glutamate uptake produces a model of slow neurotoxicity. Proc Natl Acad Sci USA 90:6591-6595.

Rothstein JD, Van Kammen M, Levey AI, Martin LJ, Kuncl RW (1995) Selective loss of glial glutamate transporter GLT-1 in amyotrophic lateral sclerosis. Ann Neurol 38:73-84.

Samdani AF, Newcamp C, Resink A, Facchinetti F, Hoffman BE, Dawson VL, Dawson TM (1997) Differential susceptibility to neurotoxicity mediated by neurotrophins and neuronal nitric oxide synthase. J Neurosci 17:4633-4641.

Sato T, Kamata Y, Irifune M, Nishikawa T (1997) Inhibitory effect of several nitric oxide-generating compounds on purified $\mathrm{Na}, \mathrm{K}$-ATPase activity from porcine cerebral cortex. J Neurochem 68:1312-1318.

Scavone C, Scanlon C, McKee M, Nathanson JA (1995) Atrial natriuretic peptide modulates sodium and potassium-activated adenosine triphosphatase through a mechanism involving cyclic GMP and cyclic GMP-dependent protein kinase. J Pharmacol Exp Ther 272:1036-1043.

Stadtman ER (1992) Protein oxidation and aging. Science 257:1220-1224.

Stamler JS, Singel DJ, Loscalzo J (1992) Biochemistry of nitric oxide and its redox-activated forms. Science 258:1898-1902.

Stelmashook EV, Weih M, Zorov D, Vicotrov I, Dirnagl U, Isaev N (1999) Short-term block of $\mathrm{Na}^{+} / \mathrm{K}^{+}$-ATPase in neuro-glial cell cultures of cerebellum induces glutamate-dependent damage of granule cells. FEBS Lett 456:41-44

Sweadner KJ (1989) Isozymes of the $\mathrm{Na}^{+} / \mathrm{K}^{+}$-ATPase. Biochim Biophys Acta 988:185-220.

Thevenod F, Friedmann JM (1999) Cadmium-mediated oxidative stress in kidney proximal tubule cells induces degradation of $\mathrm{Na}^{+} / \mathrm{K}^{+}$-ATPase through proteasomal and endo-/lysosomal proteolytic pathways. FASEB J 13:1751-1761.

Trotti D, Rolfs A, Danbolt NC, Brown Jr RH, Hediger MA (1999) SOD1 mutants linked to amyotrophic lateral sclerosis selectively inactivate a glial glutamate transporter. Nat Neurosci 2:427-433.

Viani P, Cervato G, Fiorilli A, Cestaro B (1991) Age-related differences in synaptosomal peroxidative damage and membrane properties. J Neurochem 56:253-258.

Watts AG, Sanchez-Watts G, Emanuel JR, Levenson R (1991) Cell-specific expression of mRNAs encoding $\mathrm{Na}^{+}, \mathrm{K}^{+}$-ATPase $\alpha$ - and $\beta$-subunit isoforms within the rat central nervous system. Proc Natl Acad Sci USA 88:7425-7429.

Wetzel RK, Arystarkhova E, Sweadner KJ (1999) Cellular and subcellular specification of $\mathrm{Na}$,K-ATPase $\alpha$ and $\beta$ isoforms in the postnatal development of mouse retina. J Neurosci 19:9878-9889.

Xie Z, Jack-Hays M, Periyasamy SM, Blanco G, Huang W-H, Askari A (1995) Different oxidant sensitivities of the $\alpha 1$ and $\alpha 2$ isoforms of $\mathrm{Na}^{+} / \mathrm{K}^{+}$ATPase expressed in baculovirus-infected insect cells. Biochem Biophys Res Commun 207:155-159.

Zolotarjova N, Ho C, Mellgren RL, Askari A, Huang W-H (1994) Different sensitivities of native and oxidized forms of $\mathrm{Na}, \mathrm{K}$-ATPase to intracellular proteinases. Biochim Biophys Acta 1192:125-131. 